Article

\title{
The Effect of Specific Energy Density on Microstructure and Corrosion Resistance of CoCrMo Alloy Fabricated by Laser Metal Deposition
}

\author{
Jinbao Li 1,2 (D), Huijiao Ren ${ }^{1,2}$, Changsheng Liu 1,2 ${ }^{1}$ and Shuo Shang 1,2,* \\ 1 School of Materials Science and Engineering, Northeastern University, Shenyang 110819, China; \\ jinbaoli@stumail.neu.edu.cn (J.L.); huijiaoren@163.com (H.R.); csliu@mail.neu.edu.cn (C.L.) \\ 2 Key Laboratory for Laser Application Technology of Liaoning Province, Northeastern University, \\ Shenyang 110819, China \\ * Correspondence: shangs@atm.neu.edu.cn
}

Received: 13 February 2019; Accepted: 11 April 2019; Published: 23 April 2019

\begin{abstract}
With the development of modern medical implants, there are significantly increasing demands for personalized prosthesis. Corrosion-resistance and dense cobalt alloy specimens have been successfully fabricated by laser metal deposition. The relationship between specific energy density, microstructure and corrosion resistance of the specimens is investigated. The results show that higher specific energy density promotes the formation of columnar grain and leads to coarse grain size. The evolution and distribution of deposited microstructure from bottom to top are summarized in a metallographic sketch. The corrosion current of deposited specimens increases from $2.071 \times 10^{-6} \mathrm{~A} / \mathrm{cm}^{2}$ to $6.86 \times 10^{-5} \mathrm{~A} / \mathrm{cm}^{2}$ and rapidly drops to $9.88 \times 10^{-7} \mathrm{~A} / \mathrm{cm}^{2}$ with increase of specific energy density from $318.8 \mathrm{~J} / \mathrm{g}$ to $2752.3 \mathrm{~J} / \mathrm{g}$. The columnar and equiaxed structure of deposited specimens have lower corrosion current than mixed structure due to finer grain and less Mo segregation. The deposited have low level metal released because of passive film. The passive film have different formation routes in Hank's solution and acidic saliva. The specific energy density has an important effect on the microstructure of deposited, which improves corrosion resistance and life span in implant.
\end{abstract}

Keywords: laser metal deposition; cobalt-based alloy; morphology; corrosion resistance

\section{Introduction}

Cobalt-chromium-molybdenum ( $\mathrm{CoCrMo}$ ) alloy is widely used in removable partial dentures and medical implant such as metal frames, customized abutments, crowns, bridges, hips, knees and ankles [1,2]. Although the stiffness of the CoCrMo alloy differs from that of human bone, CoCrMo alloys have particular advantages in medical implant for its excellent wear and corrosion resistance. Currently, around $10 \%$ of joint transplant patient total hip arthroplasty require revision surgery [3]. This proportion has been continuously increasing with the younger and more physically active group at a higher revision rate. These revisions are caused by a mismatch between implant and bone geometry and corrosion of implant. Additive manufacturing (AM) is a flexible manufacturing technology, and includes selective laser melting (SLM), electron beam melting (EBM) and laser metal deposition (LMD). The near-net-shape achieved by AM can shorten delivery time for components, thus enabling mass production of CoCrMo alloys part in a cost effective manner. Customized components can be achieved through freedom of CAD design and increasing innovation [4]. Geometric accuracy is also improving as AM techniques continuously develop.

Laser metal deposition (LMD) is an additive manufacturing technique that delivers metal particles to the location of a melt pool formed by a laser beam [5,6]. It consists of a coaxial nozzle and NC 
machine tool, a cooling water machine and shielding gas to protect the molten pool created by a laser beam. With this layer by layer increment manufacturing process, the repair and production of metallic components, smart structures, and functionally graded materials can be achieved for applications in aerospace, biomedical and automobile industries [7-9]. SLM and LMD share similar fundamentals of high energy density heat sources, localized melting and microstructural evolution based upon solidification of the melt. SLM has advantages of fine surface quality and is suitable for complex internal features. However, LMD has higher efficiency and low cost per item due to its higher scanning speed and larger beam spot. It is a promising approach to solve the issues of high manufacturing cost, the mismatch between implant and bone geometry, long product cycle and biocompatibility for CoCrMo implant $[10,11]$.

In recent years, the optimization process parameters have been investigated in order to obtain full dense parts and improve mechanical properties. Do-Sik Shim et al. [12] investigated the relationship between the energy density, the powder feed rate and the single-layer height of deposited tracks with 31 sets of process parameters. A method for selecting an appropriate layer thickness setting is proposed through a feedback control process. Chongliang Zhong et al. [13] recommended several methods to reduce the porosity of the deposited based on the influence of laser power, nominal powder particle size, and on the porosity of laser deposited single tracks in LMD.

Porous structure and small-scale deposition have attracted attention due to the need for refinement and weight reduction. S. L. Campanelli et al. [14] designed a different relative density lattice structure of Ti6Al4V fabricated by SLM. The result shows that a higher energy density of laser beams causes the formation of martensitic alpha leading to higher micro-hardness. The statistical optimization was used to identify the optimal geometric configuration that maximizes peak strength and energy absorbed per unit mass. Jesús del Val et al. [15] have deposited a thin and narrow fine line with $14 \mu \mathrm{m}$ wide and $7.2 \mu \mathrm{m}$ thick by side powder injection laser micro-cladding technique. Laser irradiation and processing speed have great influence on the main geometrical features of the track. A processing map has been established to point out the working window for the process.

However, the solidification condition of LMD is different from those of traditional process due to its rapid melting and cooling rates $\left(10^{6}-10^{7}{ }^{\circ} \mathrm{C} / \mathrm{s}\right)$. Fine micro-structure, non-equilibrium phase, and anisotropy of mechanical properties have been investigated according to the influence of process parameters on melt pool that is considered as a common phenomenon in metal additive manufacturing process [16]. The unique solidification condition and reasonable design of porous structure give the deposited samples excellent mechanical properties such as compressive and fatigue properties [17,18].

For CoCrMo parts, multiple researches focused on the microstructure and its mechanical properties between AM and casting. Furthermore, the cardiovascular stents using a $\mathrm{CoCr}$ alloy was successfully fabricated by SLM which has similar surface roughness and micro-hardness compared to macro SLM components. It is a potential approach that can be treated as an alternative conventional manufacturing cycle based on microtube manufacturing and laser microcutting [19]. CoCrMo compound fabricated by AM technology usually consists of $\gamma$ (fcc) and $\varepsilon$ (hcp) phase with an intricate network of thin $\varepsilon$-lamellae distributed inside the $\gamma$ phase. It has a higher hardness than the specimen fabricated by other technique, leading to good wear resistance [20]. E. Liverani [21] had designed three scan strategies to achieve fully dense with superior mechanical strength component. The subsequent kinematic tests, carried out on a cadaver leg, confirmed that the custom-fit articular surfaces sufficiently reproduced natural joint motion. Lin Wu et al. [22] examined the mechanical properties of $\mathrm{Co}-\mathrm{Cr}$ alloy fabricated by SLM and investigated the correlation between its microstructure and mechanical properties. It is found that the SLM alloy had a dense and obviously orientated microstructure, which led to excellent mechanical properties. The mean yield strength $884.37 \mathrm{MPa}$ of the SLM alloy was notably higher than that $758.73 \mathrm{MPa}$ of currently used cast alloy.

The deposited CoCrMo specimen with excellent mechanical properties is suitable for medical implantation. Therefore, there is an increasing interest in its corrosion. Li Zeng et al. [23] tested corrosion properties with LMD and cast sample. The result shows that both samples have similar 
corrosion property in test solutions ( $\mathrm{pH}, 5.0$ or 2.5). Yolanda S. Hedberg [24] found that SLM CoCrMo alloy has higher corrosion resistance and lower metal release compared to casting, because the non-equilibrium microstructure of cellular structure that enriched in Mo at cell boundaries suppress carbide precipitation and form martensitic (hcp) phase at the surface. Xin et al. [25] investigated surface characteristics and corrosion resistance of selective laser melted $\mathrm{Co}-\mathrm{Cr}$ alloy before and after porcelain-fused-to-metal firing. The samples display similar corrosion behavior before and after firing in modified Fusayama artificial saliva. SLM specimens displayed significantly better corrosion resistance than cast specimens in modified Fusayama artificial saliva with $\mathrm{pH}$ 2.5.

The corrosion resistance of specimen fabricated by additive manufacturing is better than that of casting. However, there is still significant variance in corrosion properties between specimens [26,27]. The variance affects the lifetime and safety usage of implants. Thus, it is important to further investigate the relationship between fabrication parameters, microstructure and corrosion resistance changes of LMD specimens. In this study, the deposited specimens are fabricated to investigate the influence of specific energy density on microstructure and corrosion resistance. The amount of metal released is used to evaluate biocompatibility as well. The aim was to optimize corrosion resistance through process parameters, reveal the formation of passive film in two simulated body fluids and promote LMD industrial applications.

\section{Materials and Methods}

\subsection{Experimental Materials and Equipment}

The LMD system (RtPrint1001, Raytech automation Co, Ltd., China) consists of a fiber laser (Rofin fl015c) that serves as the heat source, a numerical control system, a 4-axis NC machine tool and a powder delivery system consisting of one hopper and four coaxial powder nozzles. The beam spot diameter is $1.6 \mathrm{~mm}$ that measured a beam quality $\mathrm{M} 2<1.3$ with Gaussian distribution. The hatch distance of specimen is $1 \mathrm{~mm}$. The machining head, equipped with coaxial powder delivery system, is integrated with an optical system including a collimator and a protective lens to feed the powder coaxially with the laser beam on the substrate surface, placed $9 \mathrm{~mm}$ from the nozzle tip. The diameter of feeding fiber core size and divergence value of fiber laser is $100 \mu \mathrm{m}$ and $33.817 \mathrm{mrad}$. The laser gets through the collimating (focal length: $80 \mathrm{~mm}$, diameter: $38 \mathrm{~mm}$ ) and focusing lens (focal length: $125 \mathrm{~mm}$, diameter: $25 \mathrm{~mm}$ ) to from the molten pool on the substrate. Argon is used as shielding gas from the middle of machining head with $7 \mathrm{~L} / \mathrm{min}$ as well as carrying gas for the injected powder with $3 \mathrm{~L} / \mathrm{min}$. The elevated height of each layer for machining head $\Delta \mathrm{Z}$ is $0.5 \mathrm{~mm}$. The schematic of LMD processing assembly and a structural sketch of machining head is shown in Figure 1a,b.

The substrate materials are 316L stainless steel with the dimension of $100 \mathrm{~mm} \times 60 \mathrm{~mm} \times 8 \mathrm{~mm}$. The gas atomized powder produced by Shenyang Research Institute of Nonferrous Metals is used for the deposition. The powder particles size is in the range of 50-150 $\mu \mathrm{m}$. The composition of powder and substrate are shown in Table 1. The deposited specimens were fabricated on various specific energy with the dimension of $10 \mathrm{~mm} \times 10 \mathrm{~mm} \times 10 \mathrm{~mm}$, as shown in Figure 1c. The various specific energy density is designed to fabricate specimens and process parameters of the experiment are shown in Table 2. The specific energy reflects thermal condition and history of the specimens, as well as the relationship between input energy and feeding rate. Figure $1 \mathrm{~d}$ shows that the actual layer height is proportional to specific energy density. The actual layer height is kept in an acceptable range from $527.1 \mu \mathrm{m}$ to $652.9 \mu \mathrm{m}$. However, excessive specific energy density results in capturing more particles that gives a broad layer thickness according to our previous work. When the actual layer thickness mismatch with a setting height of machining head $(\Delta z=0.5 \mathrm{~mm})$, the laser beam and powder flow cannot focus on one point. Thus, the process will fail because over-high actual layer thickness makes the machining head touch the specimen or over-low actual layer thickness makes the specimen no longer grow, as shown in Figure 1d. 

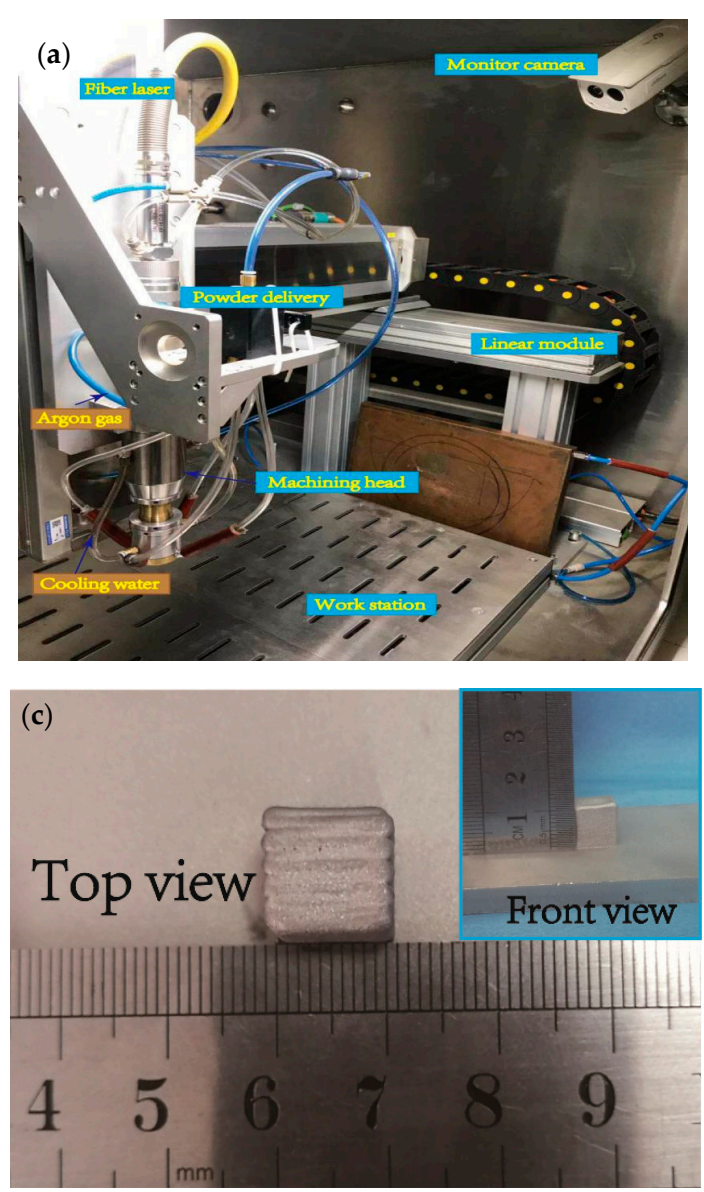
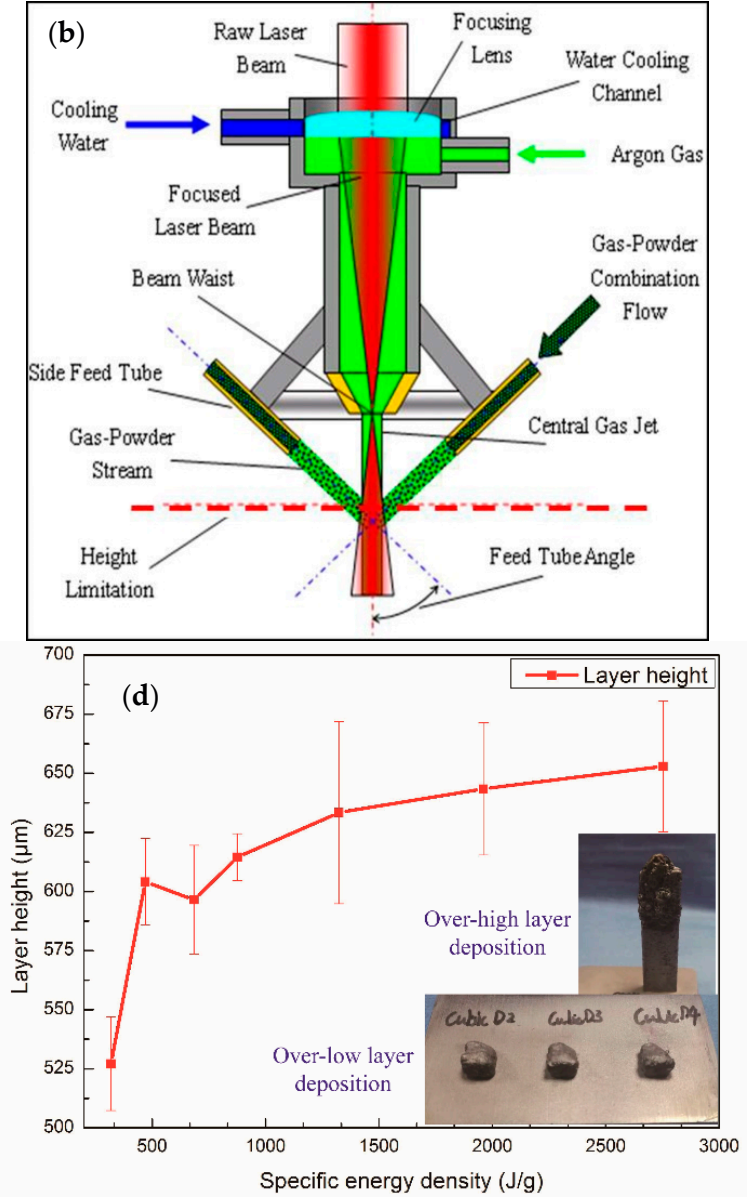

Figure 1. (a) The schematic of Laser metal deposition LMD processing assembly; (b) Structural sketch of machining head; (c) Macro-photograph of the deposited specimens; (d) The influence of specific energy density on actual layer height (bottom insert graph: the fail specimen with unreasonable parameters in previous work).

Table 1. Nominal chemical composites of the Co21 alloy and substrate in wt.\%.

\begin{tabular}{ccccccccccc}
\hline Co21 & Cr & Mo & C & Fe & W & Ni & Si & S & P & Co \\
\hline Content (wt.\%) & 27.26 & 8.56 & 0.24 & 1.07 & 0.07 & 3.58 & 1.14 & 0.012 & 0.002 & Bal \\
\hline 316L & $\mathrm{C}$ & $\mathrm{Cr}$ & $\mathrm{Ni}$ & $\mathrm{Mo}$ & $\mathrm{Mn}$ & $\mathrm{S}$ & $\mathrm{P}$ & $\mathrm{Si}$ & $\mathrm{N}$ & $\mathrm{Fe}$ \\
\hline Content (wt.\%) & 0.016 & 16.33 & 10.24 & 2.05 & 1.11 & 0.001 & 0.019 & 0.52 & 0.025 & Bal. \\
\hline
\end{tabular}

Table 2. The parameters of laser metal deposition.

\begin{tabular}{cccccccc}
\hline Order & 1\# & 2\# & 3\# & 4\# & 5\# & 6\# & 7\# \\
\hline Power $(\mathrm{W})$ & 900 & 800 & 700 & 600 & 500 & 400 & 300 \\
\hline Powder-Feed rate $(\mathrm{g} / \mathrm{s})$ & 0.327 & 0.408 & 0.529 & 0.685 & 0.73 & 0.851 & 0.941 \\
\hline Scanning speed $(\mathrm{mm} / \mathrm{s})$ & 7 & 7 & 7 & 7 & 7 & 7 & 7 \\
\hline Line energy density $(\mathrm{J} / \mathrm{mm})$ & 128.6 & 114.3 & 100 & 85.7 & 71.4 & 57.1 & 42.9 \\
\hline $\begin{array}{c}\text { Powder-Feed rate per unit } \\
\text { length }(\mathrm{g} /(\mathrm{mm} \times \mathrm{s}))\end{array}$ & 0.047 & 0.058 & 0.076 & 0.098 & 0.104 & 0.122 & 0.134 \\
\hline Specific energy * $(\mathrm{J} / \mathrm{g})$ & 2752.3 & 1960.8 & 1323.3 & 875.9 & 684.9 & 470.1 & 318.8 \\
\hline
\end{tabular}

* Specific energy density: line energy density divided by feeding rate. 


\subsection{Microstructure and Phase Analysis}

The specimens are cut, embedded, grinded and polished with diamond paste. The samples are etched with etching solutions (CuSO4: $\mathrm{HCl}=4.05 \mathrm{~g}: 20 \mathrm{~mL}$ ), and it is performed on a field emission scanning electron microscopy (SEM, JSM-6510A, Japan Electronics Co. Ltd.) and optical microscope (OM, GX71, Olympus Co. Ltd.) for microstructural investigation. The SEM equipped with electron probe $\mathrm{X}$-ray microanalysis for analyzing micro-component. In order to identify the phase constitutions, X-ray diffraction (XRD, Japan Electronics Co. Ltd.) was used with $\mathrm{Cu} \mathrm{K} \alpha$ generated of $40 \mathrm{kV}, 40 \mathrm{~mA}$ and a scanning speed of $4 \mathrm{deg} / \mathrm{min}$ between $30^{\circ}$ and $100^{\circ}$. Group A and B are parallel group and applied with parameters from 1\# to 7\#, as shown in Table 2. They were used for grain size and grain type statistics. Interception method is selected to measure the average grain size for three random visual fields on each specimen according to GB T 6394-2002 standard.

\subsection{Corrosion Resistance Analysis}

The specimens are embedded in self-curing epoxy resin, polished with diamond paste and ultrasonically cleaned in ethanol and de-ionized water. Three groups of specimens are immersed in Hank's and acidic saliva at 35 degrees centigrade for seven days, 15 days and 30 days respectively. All samples are used for each corrosion property test, carried out with an electrochemical workstation (CS350, WuHanKeYi Co. Ltd.). Electrochemical cell uses a three-electrode system, with a saturated calomel electrode (SCE) as the reference electrode, platinum foil (Pt) electrode as the counter electrode and specimens as the working electrode. The electrolyte is either Hank's simulated body fluid or acidic saliva. The test starts with a potential scan rate of $5 \mathrm{mV} / \mathrm{s}$ at room temperature after the prepared sample potential to be stable for $15 \mathrm{~min}$.

Inductively coupled plasma mass spectrometry is used to measure ion content and XPS is utilized to identify the constituents and chemical composition of specimen surfaces with soaking seven days. The XPS spectra are background subtracted with the Shirley method. The analysis is carried out using a monochromatic $\mathrm{Al} \mathrm{Ka}$ electrode at $1486 \mathrm{eV}$ and $150 \mathrm{~W}$. The acidic saliva and Hank's solution are prepared in accordance with ISO/TR 10271 [28] standard as shown in Table 3. The volume of solution in metal release test is calculated with EN ISO 10993-12:2004 standard [29].

Table 3. The components of Hank's solution and acidic saliva.

\begin{tabular}{|c|c|c|c|c|c|c|c|c|}
\hline $\begin{array}{c}\text { Hank's } \\
\text { Solution }\end{array}$ & $\mathrm{NaCl}$ & $\mathrm{KCl}$ & $\mathrm{CaCl}_{2}$ & $\mathrm{NaHCO}_{3}$ & $\mathrm{KH}_{2} \mathrm{PO}_{4}$ & $\mathrm{MgSO}_{4} \cdot 7 \mathrm{H}_{2} \mathrm{O}$ & $\mathrm{MgCl}_{2} \cdot 6 \mathrm{H}_{2} \mathbf{0}$ & Glucose \\
\hline Content $(\mathrm{g} / \mathrm{L})$ & 8 & 0.4 & 0.14 & 0.35 & 0.6 & 0.06 & 0.1 & 0.4 \\
\hline Acidic Saliva & $\mathrm{NaCl}$ & $\mathrm{KCl}$ & \multicolumn{2}{|c|}{$\mathrm{CaCl}_{2} \cdot 2 \mathrm{H}_{2} \mathrm{O}$} & Carbamide & $\mathrm{NaH}_{2} \mathrm{PO}_{4} \cdot 2 \mathrm{H}_{2} \mathrm{O}$ & $\mathrm{Na}_{2} \mathrm{~S} \cdot 2 \mathrm{H}_{2} \mathrm{O}$ & - \\
\hline Content $(\mathrm{g} / \mathrm{L})$ & 0.4 & 0.4 & \multicolumn{2}{|c|}{0.795} & 1.0 & 0.78 & 0.005 & - \\
\hline
\end{tabular}

\section{Results \& Discussion}

\subsection{Morphology and Phase Analysis}

Figure 2 shows the solidification morphology of the deposited structure. It indicates that the deposited microstructure consists of cellular grain, columnar grain and equiaxed grain. Columnar grain and equiaxed grain are the predominant microstructure of the deposited specimens, in addition, cellular grain at the bottom. The top part and interlayer junction of specimen's cross section are equiaxed grain, as depicted in Figure 2a. The top deposited layer is thicker than others because of remelting phenomenon. Columnar grain grows from the bottom of each layer, especially some columnar grain with elongation pattern and vast size, as shown in Figure $2 b$. The microcrack is also observed on the interface between substrate and the deposited due to the difference of thermal expansion coefficient between substrate and the deposited. The types of columnar grain are distinguished according to whether penetrating the interlayer. They depend on epitaxial growth which is affected by specific energy inputs. Columnar grain disrupted by equiaxed grain each layer in the middle area, like a 
sandwich structure and the vast size and penetrating the interlayer columnar grain, as shown in Figure 2c,d. The temperature gradient descents and solidification rate increases from bottom to top results in the microstructure transformation from cellular grain to equiaxed grain. If energy input is enough to remelt the equiaxed area of underlying layer with the specific energy density increase, the columnar grain will continuously grow by epitaxial growth. On the contrary, if the specific energy density is too low to remelt, the columnar grain will be blocking up. Furthermore, the increase in solidification rate leads to grain refinement.
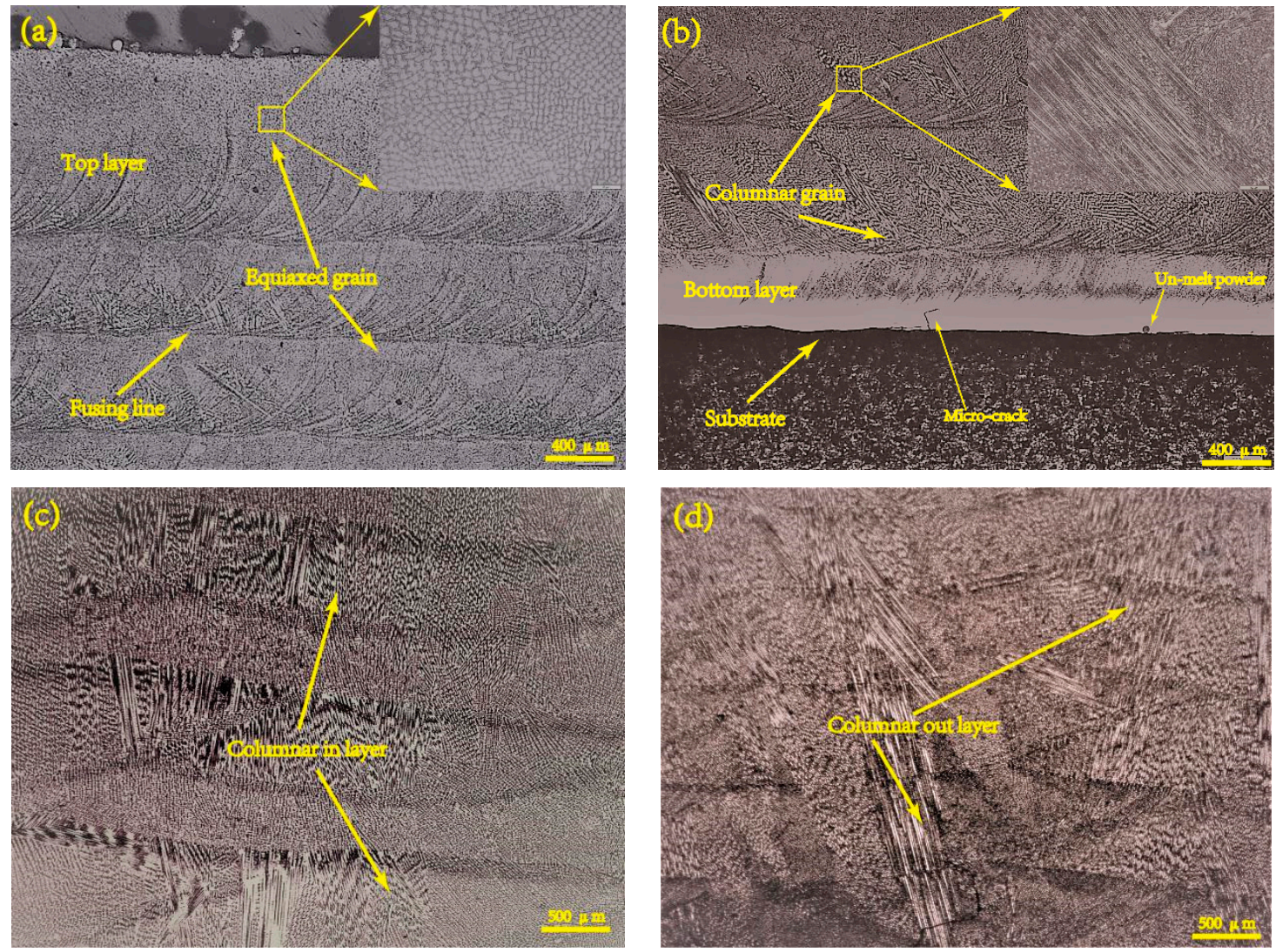

Figure 2. Optical micrograph of deposited specimens in (a) top area and (b) bottom area; two types of columnar grain $(\mathbf{c}, \mathbf{d})$ in middle area.

Figure 3a illustrates a sketch microstructure map of deposited specimens. Descent in temperature gradient and increase in solidification rate both contribute to the increase of constitutional super-cooling, resulting in diverse dendrite grain morphology. Temperature gradient $G$ and growth rate $R$ have influence on the morphology and size of solidification microstructure, as shown in Figure $3 \mathrm{~b}$. As the simulation result of multi-layer deposited [30,31], G/R and G $\times R$ is $177 \mathrm{~s} / \mathrm{mm}^{2}$ and $6010 \mathrm{~K} / \mathrm{s}$ at first layer where its second dendrite arm spacing is $1.9 \mu \mathrm{m}$. The $\mathrm{G} / \mathrm{R}$ and $\mathrm{G} \times \mathrm{R}$ is $154 \mathrm{~s} / \mathrm{mm}^{2}$ and $3980 \mathrm{~K} / \mathrm{s}$ at the sixth layer where its second dendrite arm spacing decreased to $3.1 \mu \mathrm{m}$. The developed primary dendrite, smaller second dendrite arm spacing and coarsening second dendrite will occur in a sequential order like CG1, CG2, CG3 areas in which second dendrite arm spacing increases along with deposited process continue. Moreover, the columnar grain orientation roughly is parallel to build direction. It is notable that overlapped areas consist of equiaxed and columnar grain. In this case, the equiaxed grain exhibit cross-shape like EG1, which differ from polygonous equiaxed grain on top area like EG2. 

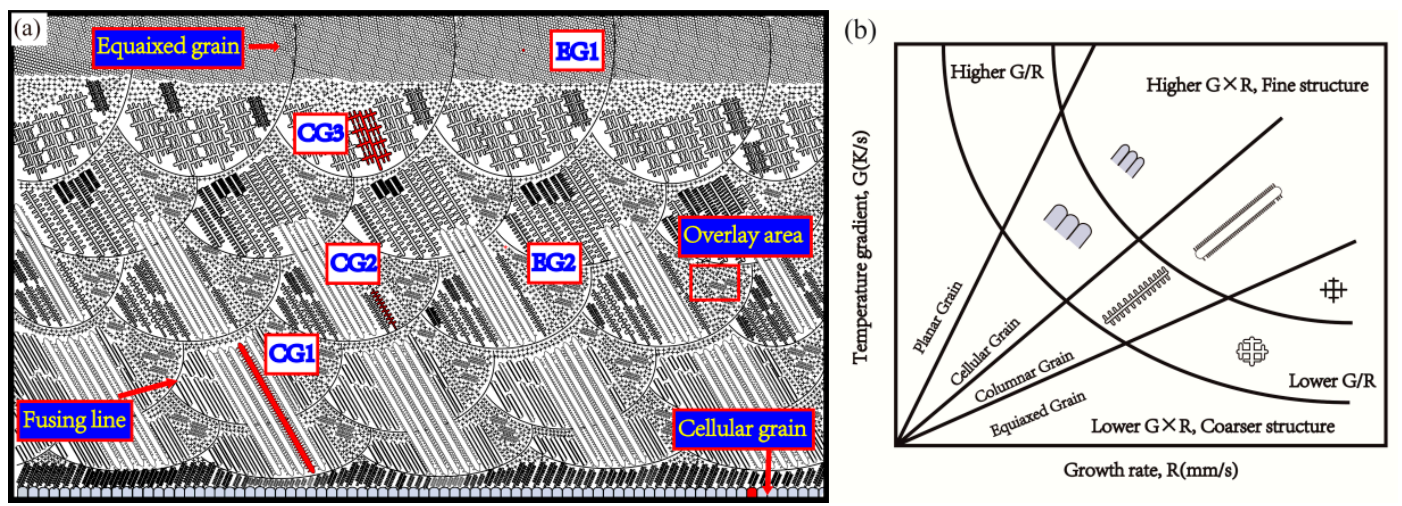

Figure 3. (a) The microstructure sketch of deposited specimen; (b) Effect of temperature gradient G and growth rate $\mathrm{R}$ on the morphology and size of solidification microstructure [32].

Figure 4 shows optical micrograph of specimens on various specific energy density from $318.8 \mathrm{~J} / \mathrm{g}$ to $2752.3 \mathrm{~J} / \mathrm{g}$. The microstructure of deposited specimen reflects its local thermal history and solidification process. Through statistics volume fraction of grain, the volume fraction of equiaxed grain decreases as specific energy increases in Figure $5 \mathrm{a}$. The volume fraction of equiaxed grain rapidly descents from $71.73 \%$ to $5.35 \%$ in the specimen of group $\mathrm{A}$, and the volume fraction in the equiaxed grain on group $\mathrm{B}$ drops from $51.46 \%$ to $4.3 \%$ as well. It is clear that the volume fraction of columnar grain increases as the specific energy increases, which shows a mechanism for competitive growth between columnar and equiaxed grains consistent with published study [33]. Grain morphology and size are influenced by nucleation and growth condition. The condition is strongly related to its thermal history. If laser power is a definite value, the input energy will be constantly used for melting powder, heating substrate and losing in environment. Thus, specific energy density reflects the degree of surplus energy within stable environment. If specific energy is higher, enough input energy not only melts powder, but also heats the substrate or previous layer. Therefore, temperature gradient of specimens increases resulting in epitaxial growth; on the contrary, it will be beneficial to the heterogeneous nucleation mechanism of equiaxed grain. The microstructure is considered as pure columnar grain if equiaxed grain is lower than $0.99 \%$. Otherwise, it is considered as pure equiaxed grain if it higher than $49 \%$ [34]. Combining statistical data of volume fraction, the deposition with specific energy density between $470.1 \mathrm{~J} / \mathrm{g}$ to $1960.8 \mathrm{~J} / \mathrm{g}$ can be considered as mixed microstructure, as depicted in Figure 4a-f. Specific energy has a small effect on grain size, as shown in Figure 5b. Higher input of specific energy density results in residual heat accumulation which decreases cooling rate and coarse grain structure is achieved. Grain size of deposited specimens remains between $8.19-10.78 \mu \mathrm{m}$. 

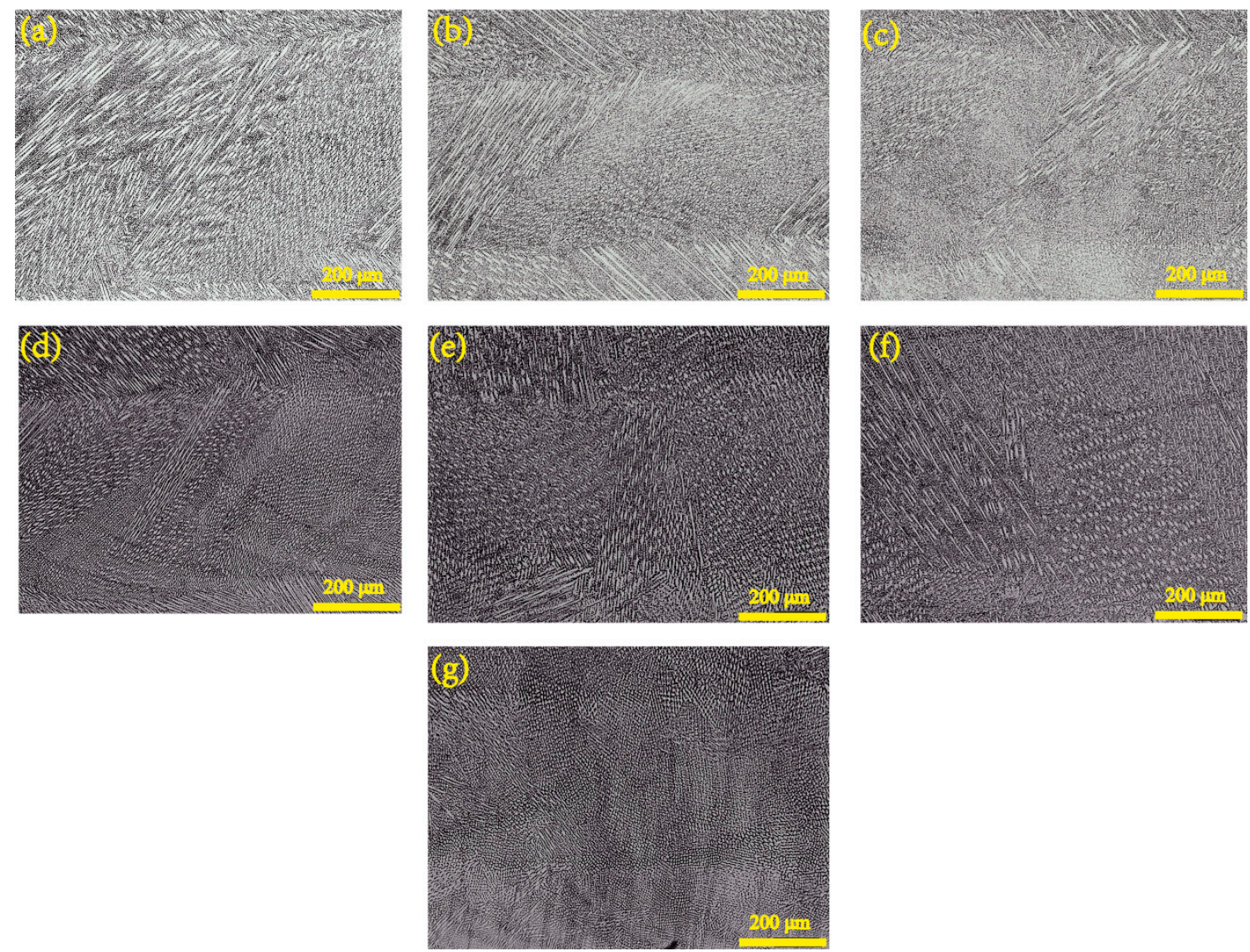

Figure 4. Optical micrograph of deposited specimens on various specific energy density. (a) $2752.3 \mathrm{~J} / \mathrm{g}$; (b) $1960.8 \mathrm{~J} / \mathrm{g}$; (c) $1323.3 \mathrm{~J} / \mathrm{g}$; (d) $875.9 \mathrm{~J} / \mathrm{g}$; (e) $684.9 \mathrm{~J} / \mathrm{g}$; (f) $470.1 \mathrm{~J} / \mathrm{g}$; (g) $318.8 \mathrm{~J} / \mathrm{g}$.

(a)

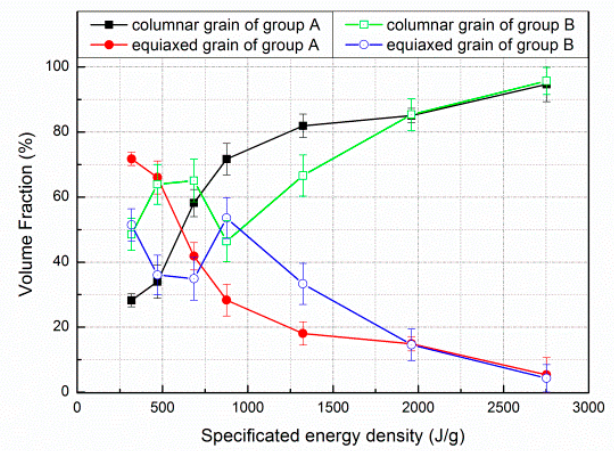

(b)

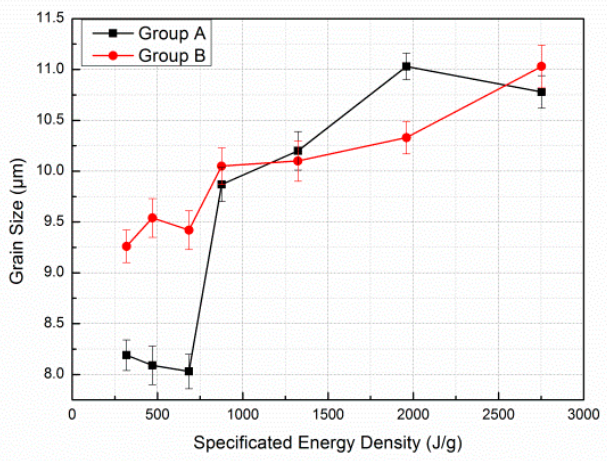

Figure 5. (a) The relationship between specific energy density and volume fraction; (b) The relationship between specific energy density and grain size.

Figure 6 shows XRD pattern of deposited specimens and powder. The $\gamma$-Co phase is observed in all specimens and powder. It is the main phase in deposited specimens and powder, which has an fcc crystallographic structure. However, $\varepsilon$-Co phase peak is also found in the deposited specimens. It is well known that LMD is a layer by layer manufacturing technology. The previous layer will be reheated and approximately cooled to $400{ }^{\circ} \mathrm{C}$ as a new layer gets deposited. The $\varepsilon$-Co, hcp structure, is a stable phase that exists from $25^{\circ} \mathrm{C}$ to $1250{ }^{\circ} \mathrm{C}$. During deposition, the average temperature of specimens maintains at $400-1100{ }^{\circ} \mathrm{C}$ [35]. Therefore, the $\gamma$ (fcc) phase has enough time to transforms to $\varepsilon$ phase during deposition process, usually takes around $30 \mathrm{~min}$. The $\varepsilon$-Co prefers to exist in lamellae shape inside $\gamma-\mathrm{Co}$, which is consistent with research findings [36]. Due to the constrained dendrite growth under super temperature gradient, the specimen has a strong anisotropy due to its thermal history and inheritance of substrate orientation. Mo mainly distributes on grain boundaries while $\mathrm{C}$ mainly 
adjacent to grain boundary from electron micro probe analysis in Figure 7. The deposited specimens undergo a rapid cooling process resulting in an undercooled melt, which suppresses the formation of micron-sized carbides and the high temperature phase $\gamma$ will be retained. Thus, the submicron-sized carbides have been found near the grain boundary as shown in Figure $7 \mathrm{~b}$, along with segregation of $C$ and Mo at grain boundary in Figure 7.

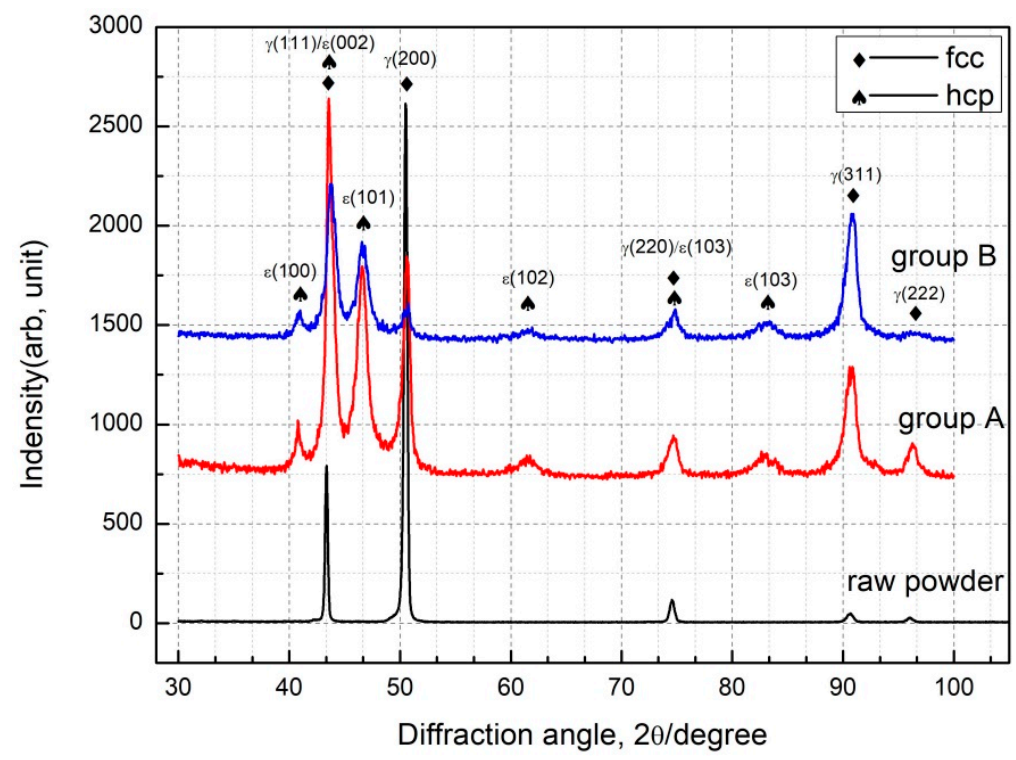

Figure 6. X-ray diffraction spectra of powder and deposited specimen.
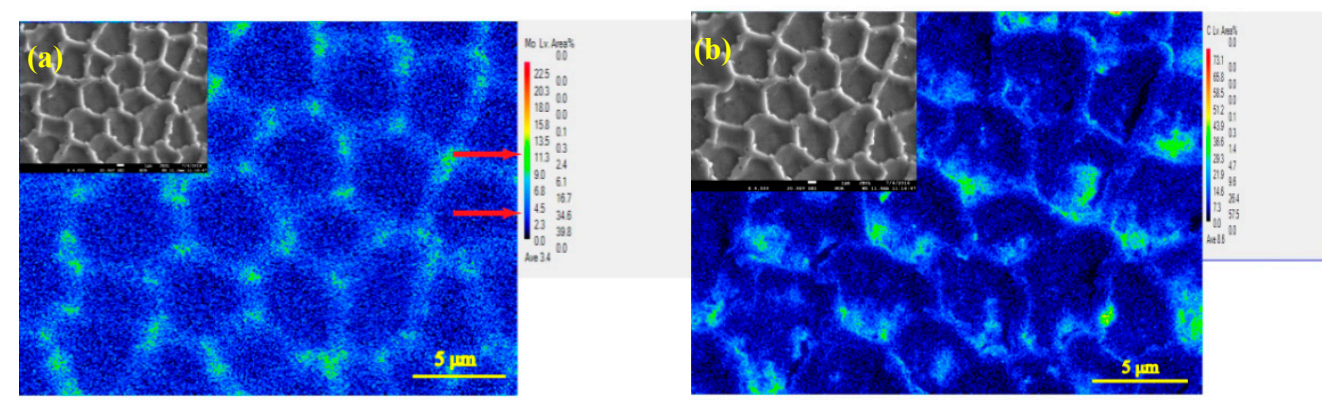

Figure 7. The electron probe micro-analyzer images of (a) Mo and (b) C.

\subsection{Corrosion Resistance of Deposited Specimen}

\subsubsection{The Effect of Specific Energy Density on Corrosion Current}

Figure 8a shows the influence of grain structure on corrosion current density in Hank's solution and acidic saliva. The grain structure of deposited specimens will transform from pure equiaxed grain to pure columnar grain with the increase of specific energy density. The corrosion current density is the highest in both Hank's solution and acidic saliva with the mixed microstructure, when specific energy density is between $470.1 \mathrm{~J} / \mathrm{g}$ to $1960.8 \mathrm{~J} / \mathrm{g}$. The specimens exhibit passive behavior in both solutions, as shown in Figure 8b. Due to existence of $\mathrm{Cl}^{-}$in Hank's and acidic saliva, pitting corrosion will occur in passive film. Therefore, current density continually increases after passive area. Higher corrosion current indicates a passive film occur pitting or it is hard to heal. On the one hand, passivation film nucleation depends on the interfacial energy, which promotes passivation film nucleation and growth [37]. The pure equiaxed grain has a finer size with greater grain boundary area than mixed structure that promotes passive film formation and improves resistance to further destruction of film. The corrosion current of a single structure like equiaxed grain is lower, because equiaxed grains 
promote corrosion resistance [38]. On the other hand, the occurrence of pitting is related to entrainment. Compared with pure columnar grain, mixed structures resulting from lower specific energy density has a lower cooling rate. It is more likely to segregate Mo and from the micron-sized carbides as discussed above. As an important anti-pitting element, Mo segregates between grains and precipitates carbide inclusions, so its corrosion current density increases.
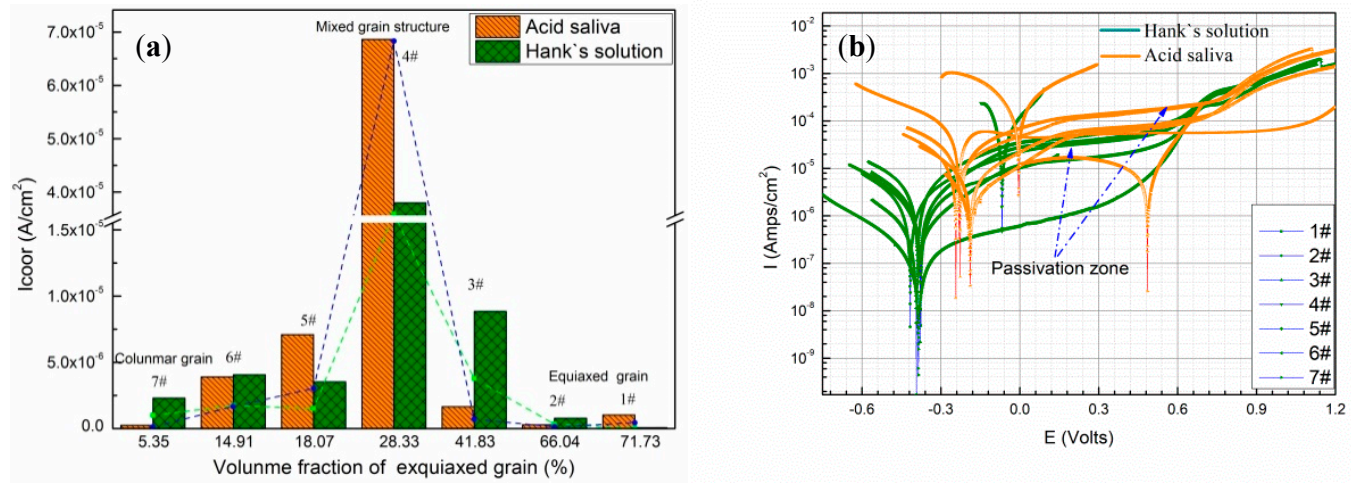

Figure 8. (a) Influence of grain structure on corrosion current in acidic saliva and Hank's solution; (b) polarization curves of deposited specimens.

Figure 8 b depicts polarization curves for deposited specimens in Hank's solution and acidic saliva. The passive region of the deposited specimen in acidic saliva is extended over a wider range of potential, generated dense and more stable passive film than in Hank's solution. The specimen in Hank's solution shows a lower corrosion potential. The corrosion current of deposited specimens for different immersion length are shown in Figure 9. The corrosion current density in acidic saliva is generally lower than that in Hank's solution. As immersion time increases, the current density in the Hank solution gradually rises, while corrosion current density in acidic saliva changes little or even declines. The deposited specimens are more stable in acidic saliva, hence immersion time has little influence on corrosion in agreement with literature study [24].

(a)

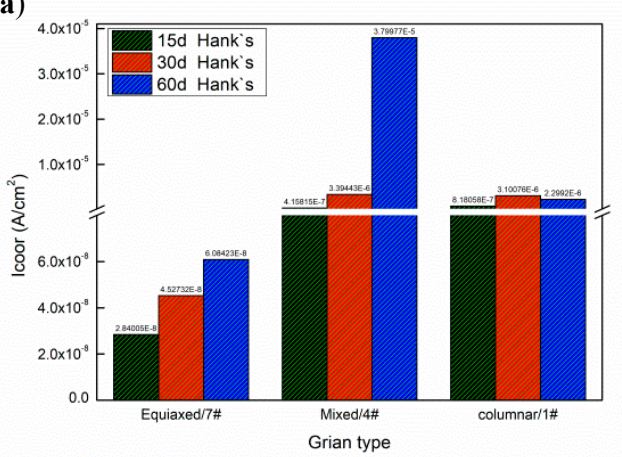

(b)

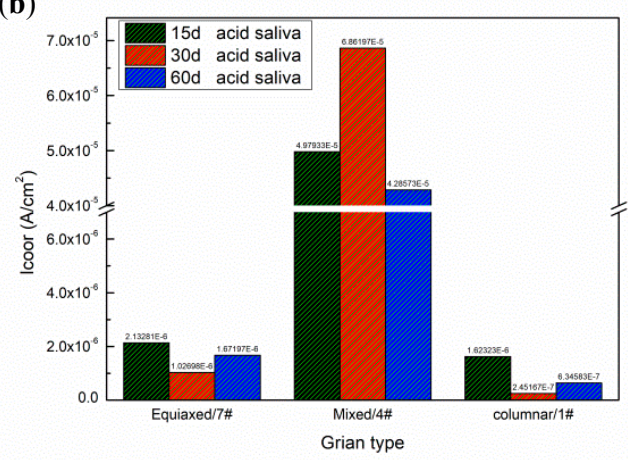

Figure 9. The corrosion current of deposited specimens with different immersion time (a) Hank's solution; (b) Acidic saliva.

\subsubsection{Passive Film Formation Analysis}

The amount of released metal for each specific energy density in Hank's solution and acidic saliva are listed in Table 4. Regardless of the influence of deposition parameters, the released amount of Co is the highest. The amount of Co reaches $1.62 \mu \mathrm{g} / \mathrm{L}$ in acidic saliva, which contains more hydrogen ions, while only reaching $0.604 \mu \mathrm{g} / \mathrm{L}$ in Hank's solution. This also applied to Mo and Cr. It is notable that deposited specimens on $318.8 \mathrm{~J} / \mathrm{g}$, the amount of ion released is much higher than other samples. The average released amount of Co, Mo Cr, Fe is $0.584 \mu \mathrm{g} / \mathrm{L}, 0.127 \mu \mathrm{g} / \mathrm{L}, 0.006 \mu \mathrm{g} / \mathrm{L}$ and $0.006 \mu \mathrm{g} / \mathrm{L}$ respectively. The amount of Co release level is in the range of $0.214-1.62 \mu \mathrm{g} / \mathrm{L}$, which is 
significantly lower than the security threshold suggested by published literature [39,40]. This indicates that deposited specimen is safe in term of ion released.

Table 4. Release amount of metal in Hank's solution and Artificial acidic saliva after seven days.

\begin{tabular}{ccccc}
\hline Acidic Saliva & $\mathrm{Co}(\mu \mathrm{g} / \mathrm{L})$ & $\mathrm{Cr}(\mu \mathrm{g} / \mathrm{L})$ & $\mathrm{Fe}(\mu \mathrm{g} / \mathrm{L})$ & $\mathrm{Mo}(\mu \mathrm{g} / \mathrm{L})$ \\
\hline $318.8 \mathrm{~J} / \mathrm{g}$ & 1.62 & 0.003 & 0.003 & 0.278 \\
\hline $875.9 \mathrm{~J} / \mathrm{g}$ & 0.214 & 0.002 & 0.002 & 0.047 \\
\hline $2752.3 \mathrm{~J} / \mathrm{g}$ & 0.441 & 0.002 & 0.003 & 0.067 \\
\hline Hank's Solution & $\mathrm{Co}(\mu \mathrm{g} / \mathrm{L})$ & $\mathrm{Cr}(\mu \mathrm{g} / \mathrm{L})$ & $\mathbf{F e}(\mu \mathrm{g} / \mathrm{L})$ & $\mathrm{Mo}(\mu \mathrm{g} / \mathrm{L})$ \\
\hline $318.8 \mathrm{~J} / \mathrm{g}$ & 0.604 & 0.018 & 0.005 & 0.266 \\
\hline $875.9 \mathrm{~J} / \mathrm{g}$ & 0.337 & 0.005 & 0.011 & 0.064 \\
\hline $2752.3 \mathrm{~J} / \mathrm{g}$ & 0.288 & 0.007 & 0.012 & 0.038 \\
\hline
\end{tabular}

Figure 10 shows the XPS survey spectra of specimen after immersion in Hank's solution for seven days. XPS spectra of binding energy regions of $\mathrm{Co} 2 \mathrm{p}, \mathrm{Cr} 2 \mathrm{p}, \mathrm{Mo} 3 \mathrm{~d}, \mathrm{O}$ 1s electrons is obtained from deposited specimens. Each spectrum is decomposed into spectra originating from both metallic and oxide states. The high resolution of binding energy are shown in Figure $10 \mathrm{~b}-\mathrm{d}$. The peaks spacing between $\mathrm{Cr} 2 \mathrm{p}_{1 / 2}$ and $\mathrm{Cr} 2 \mathrm{p}_{3 / 2}$ is $9.7 \mathrm{eV}$, which revealed the predominate presence of $\mathrm{Cr}_{2} \mathrm{O}_{3}$, while the side of small peak can be identified as $\mathrm{Cr}^{0}$. The peaks spacing between $\mathrm{Co} 2 \mathrm{p}_{1 / 2}$ and $\mathrm{Co} 2 \mathrm{p}_{3 / 2}$ is $15.8 \mathrm{eV}$, which is identified as $\mathrm{Co}, \mathrm{Co}^{3+}$ and $\mathrm{Co}^{2+}$ coinciding with published data [41]. The broad asymmetric shape for the $\mathrm{O} 1 \mathrm{~s}$ peak indicated the presence of both metal oxides and hydroxides [42]. According to binding energy data [43], the position of the Mo 3d $5 / 2$ peak in $\mathrm{Mo}^{4+}$ and $\mathrm{Mo}^{6+}$ oxide should be $229 \mathrm{eV}$ and $232.6 \mathrm{eV}$, respectively. Therefore, the binding energy obtained is consistent with the formation of $\mathrm{Mo}^{6+}$ compound in this study. The surface of deposited specimen contains $\mathrm{Co}^{0}, \mathrm{Co}^{2+}, \mathrm{Co}^{3+}, \mathrm{Mo}^{6+}$, $\mathrm{Cr}^{3+}, \mathrm{O}^{2-}$, and $\mathrm{OH}^{-}$with immersion in Hank's solution. $\mathrm{Co}$ and $\mathrm{H}_{2} \mathrm{O}$ from the complex compounds in solution [44], thus the passive films consist of $\mathrm{CoO}, \mathrm{Co}_{3} \mathrm{O}_{4}, \mathrm{CoOOH}, \mathrm{Cr}_{2} \mathrm{O}_{3}$ and minor $\mathrm{MoO}_{3}$.
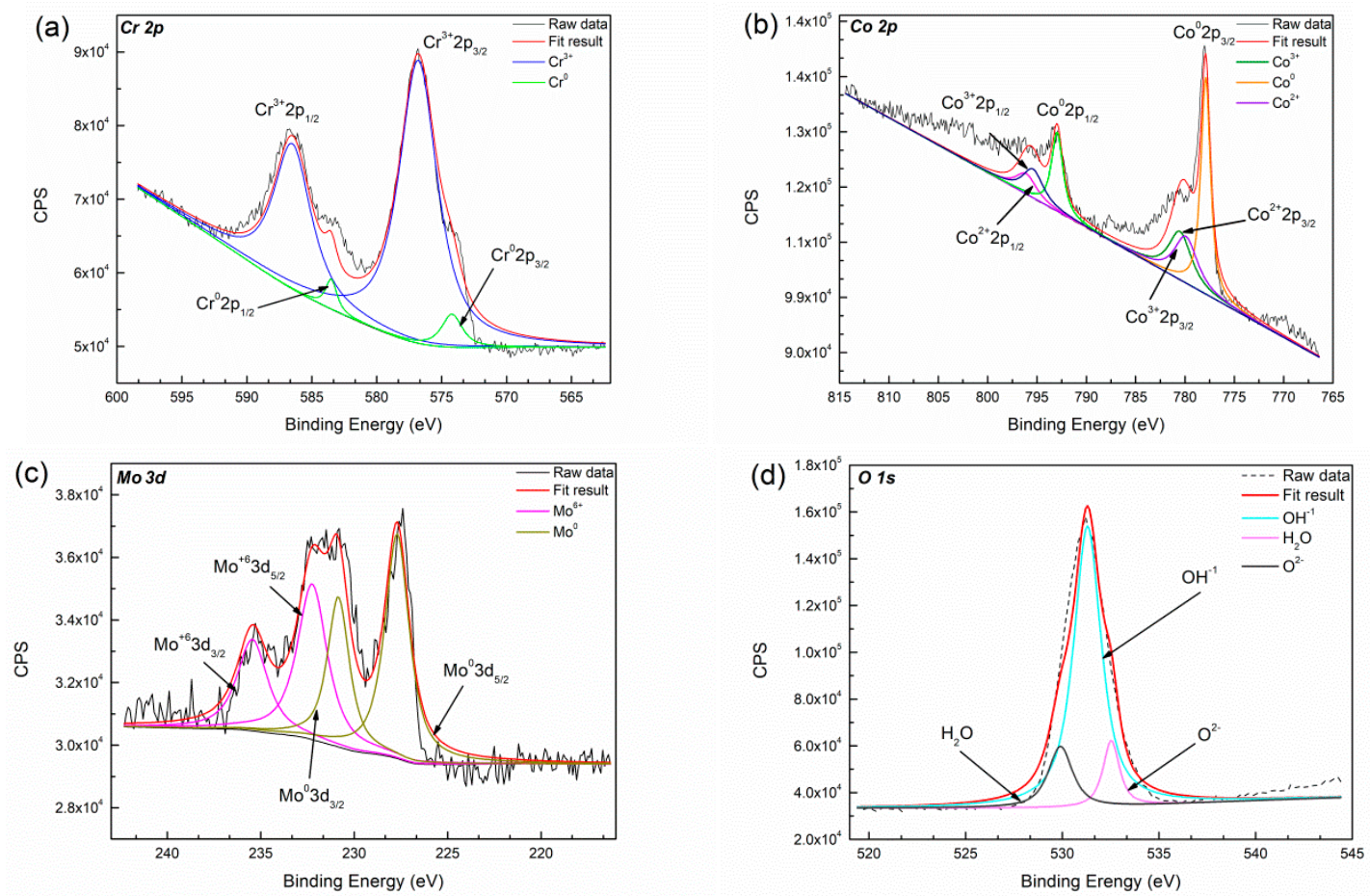

Figure 10. The X-ray photoelectron spectroscopy results of the specimen after immersion in Hank's solution for seven days (a) $\mathrm{Cr}$; (b) Co; (c) Mo; (d) O. 
Then, the corrosion process of Co can be modeled as the following:

$$
\mathrm{Co}+\mathrm{H}_{2} \mathrm{O} \rightarrow \mathrm{Co}\left(\mathrm{H}_{2} \mathrm{O}\right) \text { ads }
$$

Reaction 1:

$$
\begin{gathered}
\mathrm{Co}\left(\mathrm{H}_{2} \mathrm{O}\right) \text { ads } \rightarrow \mathrm{Co}(\mathrm{OH})^{+}+\mathrm{H}^{+}+2 \mathrm{e}^{-} \\
\mathrm{Co}(\mathrm{OH})^{+}+\mathrm{OH}^{-} \rightarrow \mathrm{Co}(\mathrm{OH})_{2} \\
\mathrm{Co}(\mathrm{OH})_{2} \rightarrow \mathrm{CoO}+\mathrm{H}_{2} \mathrm{O}
\end{gathered}
$$

Reaction 2:

$$
\begin{gathered}
\mathrm{Co}(\mathrm{OH})_{2}+\mathrm{OH}^{-} \rightarrow \mathrm{CoOOH}+\mathrm{H}_{2} \mathrm{O}+\mathrm{e}^{-} \\
3 \mathrm{CoO}+2 \mathrm{OH}^{-} \rightarrow \mathrm{Co}_{3} \mathrm{O}_{4}+\mathrm{H}_{2} \mathrm{O}+2 \mathrm{e}^{-}
\end{gathered}
$$

Figure $11 \mathrm{~b}$ depicts the binding energy of cobalt in high resolution. The peaks spacing between Co $2 \mathrm{p}_{1 / 2}$ and Co $2 \mathrm{p}_{3 / 2}$ is $15.05 \mathrm{eV}$, which indicates Cobalt does not appear on the surface in the form of ions. The Mo and $\mathrm{Cr}$ elements do not show obvious difference with immersion in acidic saliva, as shown in Figure $11 \mathrm{c}, \mathrm{d}$.

(a)

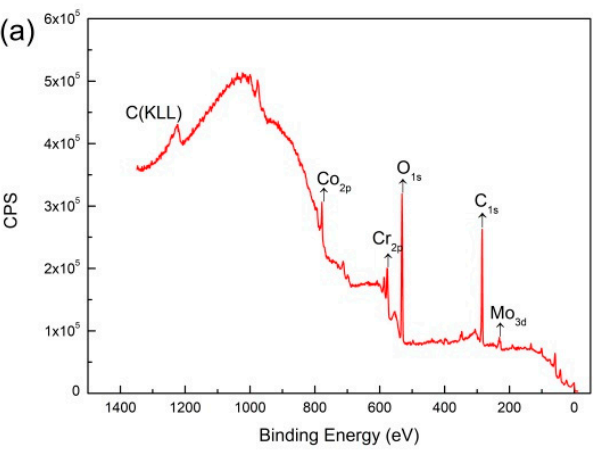

(c)

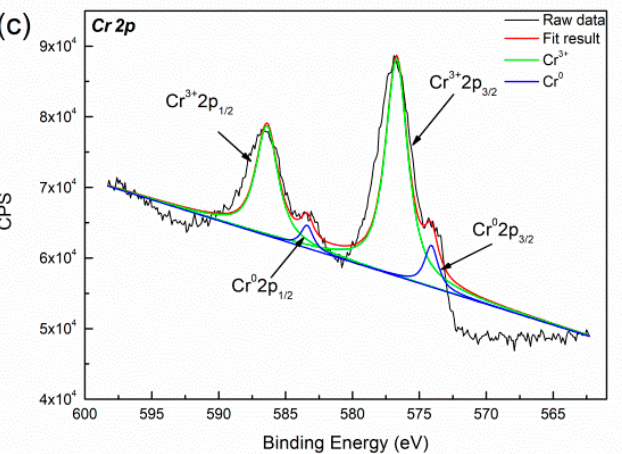

(b)

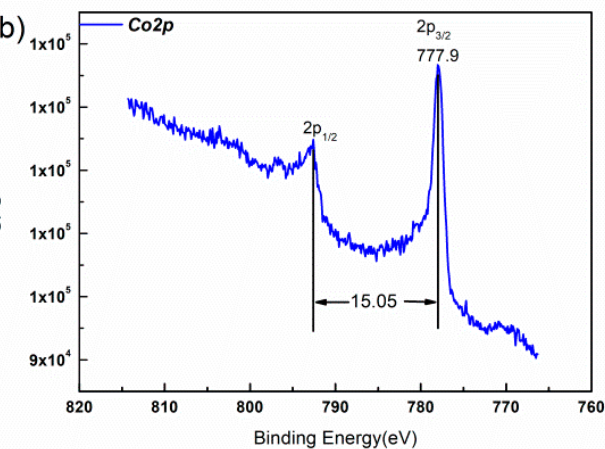

(d)

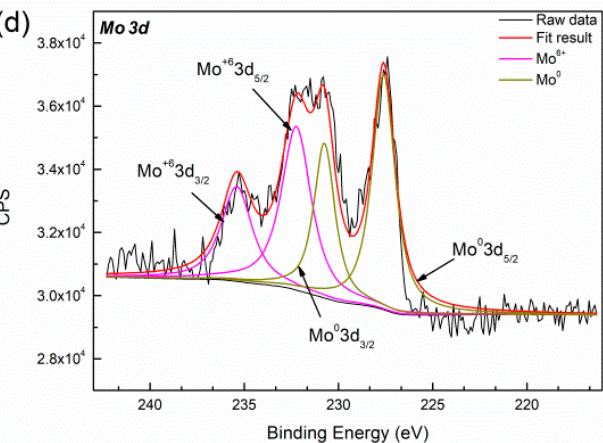

Figure 11. The survey spectra of the specimen after immersion in artificial acidic saliva for 7 days, (a) full spectrum scanning; (b) Co; (c) Cr; (d) Mo.

Co-based alloy is liable to passivation and shows lower corrosion rates in slightly alkaline or neutral corrosion solutions such as $\mathrm{NaOH}$ and $\mathrm{NaCl}$ [38]. The specimen also exhibits lower corrosion current in Hank's solution than those in acidic saliva, as mentioned above. Their results are consistent. However, $\mathrm{Co}^{3+}$ is not detected on the surface of specimen after immersed in acidic saliva for seven days. $\mathrm{Cr}$ makes a major contribution to passive film formation. The passive films consist of $\mathrm{Cr}_{2} \mathrm{O}_{3}$ and minor $\mathrm{MoO}_{3}$ in acidic saliva. The level ion release of $\mathrm{Cr}$ in acidic saliva still remains very low $0.002 \mathrm{mg} / \mathrm{L}$, and $\mathrm{Co}$ in Hank's solution is much lower than in acidic saliva. It certifies composition of passive film from another point of view. The stabilized and broadened passivation region is formed in acidic saliva 
due to the formation of dense, stable and relatively good protective passive film. Therefore, with the increase of immersion time, the corrosion rate of specimen in saliva acid changes little. The passive film contains $\mathrm{Co}(\mathrm{OH})_{2}$ will be dissolved in Hank's solution.

\section{Conclusions}

This work studied the influence of specific energy density on microstructure and corrosion resistance of Cobalt based alloy specimens fabricated by LMD. The major results are as follows:

(1) The main phases observed in deposited specimens are $\gamma$-Co and partially transformed in $\varepsilon$-Co with the deposition processing. Equiaxed and columnar grain have a competitive growth mechanism in deposited specimens. The second dendrite arm spacing of columnar grain increases from bottom to top. Higher specific energy density promotes the formation of columnar grain and leads to coarse grain size.

(2) The corrosion current of deposited specimens increases from $2.071 \times 10^{-6} \mathrm{~A} / \mathrm{cm}^{2}$ to $6.86 \times 10^{-5} \mathrm{~A} / \mathrm{cm}^{2}$ and rapidly drops to $9.88 \times 10^{-7} \mathrm{~A} / \mathrm{cm}^{2}$ with increase of specific energy density from $318.8 \mathrm{~J} / \mathrm{g}$ to $2752.3 \mathrm{~J} / \mathrm{g}$. The columnar and equiaxed structure of deposited specimens have lower corrosion current than mixed structure due to finer grain and less Mo segregation.

(3) The deposited specimens in acidic saliva forms a more stable, dense passive film than that in Hank's solution. The passive film is composed of $\mathrm{Cr}_{2} \mathrm{O}_{3}$ and displays a wide range of passivation in acidic saliva, while it consists of $\mathrm{CoO}, \mathrm{Co}_{3} \mathrm{O}_{4}, \mathrm{CoOOH}, \mathrm{Cr}_{2} \mathrm{O}_{3}$ and minor $\mathrm{MoO}_{3}$ and shows a lower corrosion potential in Hank's solution. The component fabricated by LMD has low level of released metal in both solutions.

Based on rapid solidification of thermal and material transmission in LMD, the specific energy density reflect the relationship between input energy and feedstock powder that has a strong influence on solidification microstructure. It is an effective way to simplify the number of process parameters to be evaluated and make a deep understanding for LMD process to improve corrosion resistance of the deposited part. If further normalized parameters can be used to the alloys with complex phase structures and porous structure, it will promote the commercial application and upgrade manufacturing services of LMD technology.

Author Contributions: Data curation, H.R.; Formal analysis, J.L.; Investigation, J.L. and H.R.; Methodology, S.S.; Project administration, C.L.; Supervision, C.L. and S.S.; Writing-original draft, J.L.; Writing-review \& editing, C.L. and S.S.

Funding: This research was funded by the Joint Funds of National Natural Science Foundation-Liaoning [grant numbers U1508213]; National Key R\&D Program of China [grant number 2017YFB0305801]; Fundamental Research Funds for the Central Universities [grant number N170213020]; and the National Natural Science Foundation of China [grant number 51771051].

Conflicts of Interest: The authors declare no conflict of interest.

\section{References}

1. Lindahl, C.; Xia, W.; Engqvist, H.; Snis, A.; Lausmaa, J.; Palmquist, A. Biomimetic calcium phosphate coating of additively manufactured porous CoCr implants. Appl. Surf. Sci. 2015, 353, 40-47. [CrossRef]

2. Gatto, A.; Bortolini, S.; Iuliano, L. Characterization of Selective Laser Sintered Implant Alloys: Ti6Al4V And Co-Cr-Mo. In Global Product Development; Bernard, A., Ed.; Springer: Berlin/Heidelberg, Germany, 2011; pp. 729-736.

3. Hazlehurst, K.B.; Wang, C.J.; Stanford, M. The potential application of a Cobalt Chrome Molybdenum femoral stem with functionally graded orthotropic structures manufactured using Laser Melting technologies. Med. Hypotheses 2013, 81, 1096-1099. [CrossRef] [PubMed]

4. Guo, L.; Qiu, J. Combination of cloud manufacturing and 3D printing: Research progress and prospect. Int. J. Adv. Manuf. Technol. 2018, 96, 1929-1942. [CrossRef] 
5. Thompson, S.M.; Bian, L.; Shamsaei, N.; Yadollahi, A. An overview of Direct Laser Deposition for additive manufacturing; Part I: Transport phenomena, modeling and diagnostics. Addit. Manuf. 2015, 8, 36-62. [CrossRef]

6. Zhang, X.; Li, W.; Chen, X.; Cui, W.; Liou, F. Evaluation of component repair using direct metal deposition from scanned data. Int. J. Adv. Manuf. Technol. 2018, 95, 3335-3348. [CrossRef]

7. Matthews, M.J.; Guss, G.; Khairallah, S.A.; Rubenchik, A.M.; Depond, P.J.; King, W.E. Denudation of metal powder layers in laser powder bed fusion processes. Acta Mater. 2016, 114, 33-42. [CrossRef]

8. Qiu, C.; Ravi, G.A.; Attallah, M.M. Microstructural control during direct laser deposition of a $\beta$-titanium alloy. Mater. Des. 2015, 81, 21-30. [CrossRef]

9. Mahamood, R.M.; Akinlabi, E.T. Scanning speed and powder flow rate influence on the properties of laser metal deposition of titanium alloy. Int. J. Adv. Manuf. Technol. 2017, 91, 2419-2426. [CrossRef]

10. Takaichi, A.; Suyalatu, S.; Nakamoto, T.; Joko, N.; Nomura, N.; Tsutsumi, Y.; Migita, S.; Doi, H.; Kurosu, S.; Chiba, A. Microstructures and mechanical properties of Co-29Cr-6Mo alloy fabricated by selective laser melting process for dental applications. J. Mech. Behav. Biomed. Mater. 2013, 21, 67-76. [CrossRef] [PubMed]

11. Gradzka-Dahlke, M.; Dabrowski, J.R.; Dabrowski, B. Modification of mechanical properties of sintered implant materials on the base of Co-Cr-Mo alloy. J. Mater. Process. Technol. 2008, 204, 199-205. [CrossRef]

12. Shim, D.-S.; Baek, G.-Y.; Seo, J.-S.; Shin, G.-Y.; Kim, K.-P.; Lee, K.-Y. Effect of layer thickness setting on deposition characteristics in direct energy deposition (DED) process. Opt. Laser Technol. 2016, 86, 69-78. [CrossRef]

13. Zhong, C.; Gasser, A.; Schopphoven, T.; Poprawe, R. Experimental study of porosity reduction in high deposition-rate Laser Material Deposition. Opt. Laser Technol. 2015, 75, 87-92. [CrossRef]

14. Campanelli, S.L.; Contuzzi, N.; Ludovico, A.D.; Caiazzo, F.; Cardaropoli, F.; Sergi, V. Manufacturing and Characterization of Ti6Al4V Lattice Components Manufactured by Selective Laser Melting. Materials 2014, 7, 4803-4822. [CrossRef] [PubMed]

15. Del Val, J.; Comesaña, R.; Riveiro, A.; Lusquiños, F.; Quintero, F.; Boutinguiza, M.; Pou, J. Laser direct writing of Co-superalloy lines for micro-fabrication applications. Surf. Coat. Technol. 2018, 345, 76-88. [CrossRef]

16. Fotovvati, B.; Wayne, S.F.; Lewis, G.; Asadi, E. A Review on Melt-Pool Characteristics in Laser Welding of Metals. Adv. Mater. Sci. Eng. 2018. [CrossRef]

17. Ahmadi, S.M.; Yavari, S.A.; Wauthle, R.; Pouran, B.; Schrooten, J.; Weinans, H.; Zadpoor, A.A. Additively Manufactured Open-Cell Porous Biomaterials Made from Six Different Space-Filling Unit Cells: The Mechanical and Morphological Properties. Materials 2015, 8, 1871-1896. [CrossRef]

18. Fotovvati, B.; Namdari, N.; Dehghanghadikolaei, A. Fatigue performance of selective laser melted Ti6Al4V components: State of the art. Mater. Res. Express 2019, 6, 012002. [CrossRef]

19. Demir, A.G.; Previtali, B. Additive manufacturing of cardiovascular CoCr stents by selective laser melting. Mater. Des. 2017, 119, 338-350. [CrossRef]

20. Barucca, G.; Santecchia, E.; Majni, G. Structural characterization of biomedical Co-Cr-Mo components produced by direct metal laser sintering. Mater. Sci. Eng. C 2015, 48, 263-269. [CrossRef]

21. Liverani, E.; Fortunato, A.; Leardini, A. Fabrication of Co-Cr-Mo endoprosthetic ankle devices by means of Selective Laser Melting (SLM). Mater. Des. 2016, 106, 60-68. [CrossRef]

22. Wu, L.; Zhu, H. Evaluation of the mechanical properties and porcelain bond strength of cobalt-chromium dental alloy fabricated by selective laser melting. J. Prosthet. Dent. 2013, 111, 51-55. [CrossRef] [PubMed]

23. Zeng, L.; Xiang, N.; Wei, B. A comparison of corrosion resistance of cobalt-chromium-molybdenum metal ceramic alloy fabricated with selective laser melting and traditional processing. J. Prosthet. Dent. 2014, 112, 1217-1724. [CrossRef] [PubMed]

24. Hedberg, Y.S.; Qian, B.; Shen, Z. In vitro biocompatibility of CoCrMo dental alloys fabricated by selective laser melting. Dent. Mater. 2014, 30, 525-534. [CrossRef]

25. Xin, X.Z.; Chen, J.; Xiang, N.; Gong, Y.; Wei, B. Surface characteristics and corrosion properties of selective laser melted Co-Cr dental alloy after porcelain firing. Dent. Mater. 2014, 30, 263-270. [CrossRef] [PubMed]

26. Zhi, L. Study on Mechanical Property and Corrosion Behavior of Co-Cr Alloy Fabricated by Laser Rapid Forming Technology. Master's Thesis, Fourth Military Medical University, Xi'an, China, 2010.

27. Wang, Y.-D.; Yang, Y.-Q.; Song, C.-H.; Liu, F.-M.; Mai, S.-Z. Process optimization and electrochemical behavior of CoCrMo alloy fabricated by selective laser melting based on response surface method. Chin. J. Nonferr. Met. 2014, 24, 2497-2505. 
28. International Organization for Standardization. Dentistry-Corrosion Test Methods for Metallic Materials, 2nd ed.; ISO 10271; ISO: Geneva, Switzerland, 2011.

29. Biological Evaluation of Medical Devices-Part12: Sample Preparation and Reference Materials, English version: EN ISO 10993-12; European Committee for Standardization: Brussels, Belgium, 2012.

30. Gan, Z.; Liu, H.; Li, S.; He, X.; Yu, G. Modeling of thermal behavior and mass transport in multi-layer laser additive manufacturing of Ni-based alloy on cast iron. Int. J. Heat Mass Transf. 2017, 111, 709-722. [CrossRef]

31. Gan, Z.; Yu, G.; He, X.; Li, S. Numerical simulation of thermal behavior and multicomponent mass transfer in direct laser deposition of Co-base alloy on steel. Int. J. Heat Mass Transf. 2017, 104, 28-38. [CrossRef]

32. Milos`ev, I.; Strehblow, H.-H. The composition of the surface passive film formed on CoCrMo alloy in simulated physiological solution. Electrochim. Acta 2003, 48, 2767-2774. [CrossRef]

33. Wang, T.; Zhu, Y.Y.; Zhang, S.Q.; Tang, H.B.; Wang, H.M. Grain morphology evolution behavior of titanium alloy components during laser melting deposition additive manufacturing. J. Alloy. Compd. 2015, 632, 505-513. [CrossRef]

34. Huang, W.D.; Lin, X.; Chen, J.; Liu, Z.X.; Li, Y.M. Laser solid forming. In Formation Principle of Laser Solid Forming, 3rd ed.; Lei, J., Ed.; Northwestern Polytechnical University Press: Xi'an, China, 2007; pp. 107-108.

35. Gale, W.F.; Totemeier, T.C. Smithells Metals Reference Book, 8th ed.; Elsevier Butterworth-Heinemann: Burlington, NJ, USA, 2004.

36. Girardin, E.; Barucca, G.; Mengucci, P.; Fiori, F.; Bassoli, E.; Gatto, A.; Iuliano, L.; Rutkowski, B. Biomedical Co-Cr-Mo components produced by Direct Metal Laser Sintering. Mater. Today Proceed. 2016, 3, 889-897. [CrossRef]

37. Kou, S. Welding Metallurgy, 2nd ed.; John Wiley \& Sons, Inc.: Hoboken, NJ, USA, 2003.

38. Wang, L.; Lin, Y.; Zeng, Z.; Liu, W.; Xue, Q.; Hu, L.; Zhang, J. Electrochemical corrosion behavior of nanocrystal line Co coatings explained by higher grain boundary density. Electrochim. Acta 2007, 52, 4342-4350. [CrossRef]

39. Liu, C. Microstructure and Antibacterial Property of CoCrMoCu Alloy. Master's Thesis, Jiamusi University, Jiamusi, China, 2015.

40. Lu, Y.; Wu, S.; Gan, Y.; Li, J.; Zhao, C.; Lin, J. Investigation on the microstructure, mechanical property and corrosion behavior of the selective laser melted $\mathrm{CoCrW}$ alloy for dental application. Mater. Sci. Eng. C 2015, 49, 517-525. [CrossRef] [PubMed]

41. Hagelin-Weaver, H.A.E.; Hoflund, G.B.; Minahan, D.M.; Salaita, G.N. Electron energy loss spectroscopic investigation of $\mathrm{Co}$ metal, $\mathrm{CoO}$, and $\mathrm{Co}_{3} \mathrm{O}_{4}$ before and after $\mathrm{Ar}^{+}$bombardment. Appl. Surf. Sci. 2004, 235, 420-448. [CrossRef]

42. Hanawa, T.; Hiromoto, S.; Asami, K. Characterization of the surface oxide film of a Co-Cr-Mo alloy after being located in quasi-biological environments using XPS. Appl. Surf. Sci. 2001, 183, 68-75. [CrossRef]

43. Wagner, C.D.; Riggs, W.M.; Davis, L.E.; Moulder, J.F.; Muilenberg, G.E. Handbook of X-ray Photoelectron Spectroscopy; Perkin-Elmer Corporation: Eden Prairie, MN, USA, 1979.

44. Ralston, K.D.; Birbilis, N. Effect of Grain Size on Corrosion: A Review. Corrosion 2010, 66, 075005-075005-13. [CrossRef]

(C) 2019 by the authors. Licensee MDPI, Basel, Switzerland. This article is an open access article distributed under the terms and conditions of the Creative Commons Attribution (CC BY) license (http://creativecommons.org/licenses/by/4.0/). 